\title{
Awareness of Medan Area Students in Demanding Against the Law of Drug Abuse, the Prevention of Radicalism and Terrorism
}

\author{
Zaini Munawir S', Abdul Lawali Hasibuan ${ }^{2}$ \\ ${ }^{1,2}$ Law Faculty of Medan Area University, Medan Indonesia \\ zaini@staff.uma.ac.id
}

\begin{abstract}
The progress of a nation can be seen from the level of legal awareness of its citizens. The higher the legal awareness of a country's population, the more orderly life of society and the state. Conversely, if the legal awareness of a country's population is low, what applies there is jungle law. Does the legal awareness of today's society need to be increased? Has it declined so much? What can we overcome in today's society related to legal awareness? In accordance with what has been stated above, that legal awareness is essentially awareness of the existence or occurrence of "unlawful" or "onrecht", let us see whether in today's society many things or events that are judged as "unlawful" or "onrecht". Indeed, the reality is that legal awareness is only being debated or crowded in the newspapers if legal awareness is declining or does not exist, if there are legal violations: drug abuse, radicalism and terrorism, murder, corruption, extortion, fraud, begal and so on. The level of legal awareness of students towards acts against the law uses four indicators, namely Legal Knowledge, Legal Understanding, Legal Attitudes and Legal Behavior.
\end{abstract}

\section{Keywords}

legal awareness; UMA students, Terrorism; illegal acts

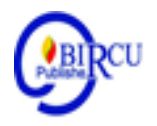

\section{Introduction}

Indonesia is a state of law, meaning that the administration of the State must be based on law so that in the administration of the State it is very important for the existence of law, and speaking of the existence of the law, to be closely related to the legal awareness of every citizen.

Based on law as regulated in the 1945 Constitution article 1 paragraph 3 which reads "The State of Indonesia is a State of Law". The inclusion of this provision in the section of the 1945 Constitution shows the strength of the legal basis and the mandate of the State, that the State of Indonesia is a State of Law. Thus it can be said that Indonesia is a country that aims to maintain law and order to realize public welfare, forming a just and prosperous society. (Rozak in Tumanggor, 2019)

Every citizen must know about the laws in force in our country. Not knowing the law is not a forgiving reason: ignorantia legis excusat neminem. This principle, which is better known as Dutch words with "iedereen wordt geacht de wet te kennen" applies in Indonesia must be instilled in education about legal awareness. This does not only mean knowing the law, but obeying it, implementing it, enforcing it, and defending it.

Awareness of what law is means awareness that law is a protection of human interests. Isn't that law a method whose function is to protect human interests? Because the number of people is large, their interests are also numerous and diverse and dynamic. Therefore it is not impossible that there will be a conflict between human interests. If all human interests can be fulfilled without disputes or disputes, if everything happens on a regular basis it will not be questioned what the law is, what the law is, who is entitled or who is guilty. 
The progress of a nation can be seen from the level of legal awareness of its citizens. The higher the legal awareness of a country's population, the more orderly life of society and the state. Conversely, if the legal awareness of a country's population is low, what applies there is jungle law.

Does the legal awareness of today's society need to be increased? Has it declined so much? What can we overcome in today's society related to legal awareness? In accordance

with what has been stated above, that legal awareness is essentially awareness of the existence or occurrence of "unlawful" or "onrecht", let us see whether in today's society many things or events that are judged as "unlawful" or "onrecht". Indeed, the reality is that legal awareness is only being debated or crowded in the newspapers if legal awareness is declining or does not exist, if there are legal violations: drug abuse, radicalism and terrorism, murder, corruption, extortion, fraud, begal and so on.

Lately there have been many violations of the law. If we follow the news in the newspapers, then it can be said that there is not a single day passed where no news about violations of law, whether in the form of violations, crimes, or in the form of acts against the law, break promises or abuse of rights. We can read the news about fraud, mugging murder, hit-and-run and so on every day in the newspapers. The sad thing is that not a few of those who know the law do so, whether they are law enforcement officers or not.

National Narcotics Agency (BNN) said drug users in Indonesia reached 5.1 million people, and it was the largest in Asia. Of that amount, $40 \%$ of them came from among students. "There are those who are curious and then try, there are those who have been addicted many times, and there are those who have become addicted and become dealers. Just trying to use the number is almost 1.2 million people.

Based on this description, the background of this research was conducted to determine the level of legal awareness of University of Medan Area Students Against Legal Abuses, Drug Abuse, Prevention of Radicalism and Terrorism.

\section{Review of Literature}

\subsection{Definition of Legal Awareness}

Consciousness comes from the word conscious. Which means convert, feel, know or understand. To realize means to know, realize, feel. Awareness means conversion, a state of understanding, things that are felt or experienced by someone.

Literally the word consciousness comes from the word conscious, which means insyaf, feel, know and understand. So consciousness is conviction or feels that understands or understands everything. Someone can not be said to be aware if they do not know the situation that is being experienced, and do not want to change the situation for the better. The term conscious means knowing or understanding about the legal actions carried out and the legal consequences, and can distinguish good from bad. Feeling and understanding that certain behaviors are regulated by law is called legal awareness.

In general, legal awareness is also associated with legal observance or legal effectiveness. In other words, legal awareness concerns the issue of whether legal provisions really function or not in society. In order for a professional harmony between the applied law and the legal awareness of the general public, the regulation itself must be rational and implemented with an orderly and reasonable procedure. Legal awareness is a concept in the sociology of law that has various meanings. Legal sociology has a very important role in the effort to socialize the law in order to increase positive legal awareness, for the community as 
a whole, as well as from law enforcers.

\subsection{Level of Public Law Awareness}

Level of Legal Awareness. According to Soekanto the indicators of legal awareness are actually relatively concrete clues about the level of legal awareness. Briefly explained again that.

1. The first indicator is legal knowledge. Someone knows that certain behaviors are regulated by law. The legal regulations referred to here are written and unwritten laws. The behavior concerns behavior that is prohibited by law or behavior that is permitted by law.

2. The second indicator is the understanding of law A student has knowledge and understanding of certain rules, for example there is a correct knowledge and understanding of students about the nature and importance of rules on campus.

3. The third indicator is the legal attitude Someone has a tendency to make certain judgments about the law.

4. The fourth indicator is legal behavior, ie where a person or student complies with applicable regulations.

These four indicators also show at certain levels of legal awareness in their realization. If someone only knows the law, then it can be said that the level of legal awareness is still low, but if someone in a society has behaved in accordance with the law, then the legal awareness is high.

\subsection{Drugs and the Law}

Narcotics, short for Nar $=$ Narcotics, $\mathrm{Ko}=$ Psychotropic, $\mathrm{Ba}=$ other dangerous addictive substances. This drug is colloquial language used by the National Police to abbreviate the three hazardous substances. The term narcotics comes from the English "Narcotics" which means anesthetic, the same meaning as "Narcosis" in Greek which means to sleep or sedate. In general, the definition of narcotics is: a substance that can cause changes in feelings, the atmosphere of observation and vision because of its effect on the central nervous system. Etymologically the term narcotics comes from the Greek word nare which means anesthetized (a deep sleep), so that it becomes numb or does not feel anything anymore. Some people think that narcotics comes from the word "narcissus" which means plants that have flowers (opiates) that can cause people to become unconscious. What is meant by narcotics in the American health encyclopedia is a drug that dulls the sense, relieves pain, induces sleep, and can produce addiction in varying degress. (drugs that dull the senses, relieve pain, induce sleep and can produce addictions to varying degrees). Therefore, the use of narcotics outside of treatment goals can cause addiction / craving. According to Law No. 35 of 2009, narcotics are defined as substances or drugs that are derived from plants or not plants, both synthesis and semisynthesis, which can cause a decrease or change of consciousness, loss of taste, reduce to eliminate pain, and can cause dependence, which is classified into 3 (three) groups. While Psychotropic according to Law No. 5 of 1997, means as a substance or natural good drug or synthesis, not narcotics that have psychoative properties through selective influence on the central nervous system that causes typical changes in mental activity and behavior.

Legal awareness is always related to humans as individuals and members of society. Humans as individuals, of course, always pay attention to themselves, while humans as members of the community will always interact or contact with other humans so that 
reactions arise between them. Awareness is an attitude / behavior to know or understand and obey the rules and provisions of the existing legislation. Awareness can also be interpreted as an attitude or behavior to know or understand and obey the customs and habits of life in society.

\subsection{Radicalism and Terrorism in Indonesian Law}

\section{a. Radicalism}

The meaning of radicalism actually, in terms of language comes from the basic word radix which means tree roots or medasar thinking, to the principle.

The meaning of the word, can be expanded, become a strong grip, belief, creator of peace and peace. Radical means more objective. So, people who think radically mean to have a more detailed and deep understanding, like a strong tree root, and determination to maintain their beliefs. This understanding, seemingly uncommon, creates a distorted impression in the community. Radicalism can be interpreted positively, namely renewal, improvement and a spirit of change towards goodness. It is hoped in the life of the nation and state of radical thinkers as a supporter of long-term reform. Thus the meaning of radicalism can be developed, into a perspective or way of thinking of someone who wants quality improvement, improvement, and peace in a multidimensional environment, so that all levels of society can live in harmony and peace.

But in reality, the meaning of radicalism itself experiences a distortion of meaning, because of the lack of viewpoints used, the general public only highlights what is done by radical groups (violent practices), which are wrong in understanding religion. So that radicalism in the name of religion is interpreted as a harsh attitude exhibited by a group of adherents of a religion, on the pretext of practicing religious teachings.

\section{b. Terrorism}

The word terror comes from the Latin terrere which can be interpreted as an activity or action that can cause fear in the community. Thus terrorism can be an ideology that likes intimidation such as acts of violence against innocent people in a country with certain motives.

The word terror comes from the Latin terrere which can be interpreted as an activity or action that can cause fear in the community. Thus terrorism can be an ideology that likes intimidation such as acts of violence against innocent people in a country with certain motives.

The definition of terrorism according to Perpu Number 1 of 2003 which is now Law Number 15 of 2003 concerning Eradication of the Criminal Acts of Terrorism, stated that what is meant by criminal acts of terrorism is any act of a person who uses violence or threat of violence that creates an atmosphere of terror or the fear of the wider public. Actions by depriving people of their liberty or eliminating the lives and property of others or destroying strategic vital objects or public / international facilities can even cause mass casualties.

From the understanding of Law No. 15 of 2003 concerning the Eradication of the Criminal Acts of Terrorism, that a person can be said to be terrorism if it fulfills the elements of: a. The actions carried out using violence and threats to create public fear. b. Aimed at certain countries, communities or individuals or groups of people. c. The group of its members by means of terror too, such as killing, destroying vital objects belonging to the state or damaging public facilities that can cause casualties. d. Commit violence with a view to getting support in a systematic and organized manner. e. The targets of terror are usually governments, ethnic groups, and political parties and so on. According to the law in Indonesia, terrorism is an extraordinary crime and can be said to be an international crime 
because of the many terrorists or terrorist groups originating from several countries. However, international law does not provide a clear definition of terrorism and the lack of clarity in international law does not make that the criminal act of terrorism free from all charges. Because according to national law, each country does not mean eliminating the evil nature of the act and thus it can be interpreted that the perpetrators of terrorism are free from all demands.

In Indonesian law, there is the word Nullum crimen sine poena, which means that no crime should be allowed to pass without punishment, but due to the fact that terrorism is no longer just an international crime and has become an international organized crime, it is very difficult to eradicate this type of crime without the existence of cooperation and common understanding among countries.

The criminal act of terrorism in criminal law in Indonesia is regulated in the Criminal Code Book II concerning crimes contained in Chapter I. About Crimes Against State Security, Chapter VII on Crimes that Endanger Public Security for People or Goods, which is part of the element of crime from the crime of terrorism. It is also found in Chapter XXVII concerning Destruction or Damage of Goods. In the Criminal Code that can be said as a criminal act of terrorism if the crime is causing chaos for the security of a country and endangering security for the general public by damage and destruction of state property that has a great impact on a country. The explanation of the criminal acts of terrorism contained in the Criminal Code as follows:

a. Article 106 to Article 108 Chapter I Regarding Crimes Against State Security, which reads:

Article 106: "Makar with the intention that the whole or part of the state's territory falls into the hands of the enemy or with the intention to separate part of the country's territory from others, threatened with life imprisonment or imprisonment for a certain period of time, a maximum of twenty years."

Article 107: (1) Makar with the intention of overthrowing the government, shall be punished with a maximum imprisonment of fifteen years. (2) The leaders and regulators of treason in paragraph 1 are threatened with life imprisonment or imprisonment for a maximum of twenty years.

Article 108: (1) "threatened with a maximum sentence of fifteen years, for a rebellion: 1. People who oppose the Government with weapons; 2. People with the intention of opposing the Government invade together with the mobs who oppose the Government with weapons. (2) The leaders and organizers of the uprising are threatened with life imprisonment or a temporary prison sentence of no more than twenty years. "

b. Article 187 VII concerning Crimes that Endanger Public Security for People or Property which reads: "Anyone who intentionally causes a fire, explosion or flood, is threatened: 1. With a maximum imprisonment of twelve years, if due to the above mentioned acts a general danger arises. for goods; 2 . With a maximum imprisonment of fifteen years, if because of the aforementioned acts arises a danger to the lives of others.

With a sentence of life in prison or for a certain period of time of no more than twenty years, if because of the above provisions, there is danger to the lives of others and results in death of people. " c. Article 406 Chapter XXVII concerning the Destruction or Destruction of Goods which reads: (1) Anyone who intentionally and unlawfully destroys, damages, renders useless or removes items which are wholly or partly owned by another person, are threatened with imprisonment no longer than two years eight a month or a maximum fine of four thousand five hundred rupiah. (2) The same sentence is imposed on a person who 
intentionally and unlawfully kills, damages, renders useless or eliminates animals, which is wholly or partly owned by another person. With the word "Makar" means every person who damages the security of the country which can be said to be a terrorist because it gives rise to a large and widespread state. And there is the word "Rebels" which can be interpreted that a terrorist is a state rebel who causes damage, destruction of goods, buildings or state facilities with fatalities or not, whether it is the use of explosives or with weapons, it can be said as a crime terrorism. In Article 406 of Book XVII concerning the Destruction or Destruction of Goods which constitutes a form of criminal acts of terrorism in addition to damaging the order of state security and the security of the general public. Although currently the criminal act of terrorism already has a law composed because the criminal act of terrorism is a special crime. And many cases of criminal acts of terrorism that no longer use the Criminal Code as punishment to prosecute perpetrators of terrorism offenses that make the Criminal Code in the aforementioned Articles are considered not to be elements of criminal acts of terrorism. 2 . According to Law Number 15 of 2003 concerning Eradication of Terrorism Crimes In general, criminal acts of terrorism have been regulated in Perpu No. 1 of 2002 concerning the eradication of terrorism offenses that have been ratified into Law Number 15 of 2003 which forms the legal basis for eradicating terrorism offenses in Indonesia, states that what is meant by terrorism offenses is as follows: acts of terrorism are all acts that fulfill criminal elements in accordance with the provisions of Government Regulation in lieu of this Act. (article 1 paragraph (1) of Law No. 15 of 2003). Article 1 paragraph (1) of Law No. 15 of 2003 concerning the eradication of the criminal act of terrorism, the formulation is the same as that contained in the draft law on criminal acts of terrorism.

While the intended elements of terrorism in Article 1 paragraph (1) of Law no. 15 of 2003 concerning the Eradication of Terrorism Acts is an act against the law with the explanation in article 6 that the criminal act of terrorism is as follows: Anyone who uses violence or threat of violence creates an atmosphere of terror or widespread fear of people or causes mass victims, by depriving others of their liberty or loss of life or property, or resulting in damage or destruction to vital strategic objects or the environment or public facilities or international facilities, sentenced to death sentence or life imprisonment or imprisonment for a minimum of 4 ( four) years and a maximum of 20 (twenty) years. Thus, the formulation of a terrorism crime contains six main elements, namely: (1) each person; (2) deliberately using violence, threat of violence; (3) creates an atmosphere of terror or fear; (4) to people extensively, or to cause mass casualties; (5) by seizing freedom or the loss of life and property of others; (6) and / or cause damage or destruction to vital objects which are strategic and environmental or public facilities or international facilities.

\section{Research Method}

\subsection{Research sites}

The location of this research is the Medan Area University by taking several faculties as samples.

\subsection{Types of research}

This research is a normative legal research. Normative legal research is research that refers to legal norms contained in legislation and court decisions. Normative legal research includes research in the form of legal inventory, research in the form of efforts to find legal principles and the basis of philosophy (dogma or doctrine) positive law and research in the form of an inconcreto legal discovery that is suitable to be applied in order to resolve a particular legal case. In the normative legal research method must contain a description 
containing the first type of research, the second approach to the problem, the third approach to the law, the fourth procedure for the collection of legal material, the fifth processing and analysis of legal materials).

\subsection{The Sources of Research}

Legal Sources This research is: secondary and primary legal sources. Primary legal sources are materials that are binding on the issues to be examined, such as laws, government regulations, jurisprudence and others. Whereas Secondary legal sources are data materials that provide an explanation of primary data legal materials. Like the results of research, scientific work and so on.

\subsection{Techniques of Collection Data}

Data collection techniques used were interview guides as well as literature studies / document studies.

\subsection{Technique of Analysis Data}

Data analysis was carried out qualitatively where data collected both secondary, primary and tertiary data were tabulated. To draw conclusions in order to answer the problem formulation, a qualitative analysis was carried out using inductive and deductive methods with the aim of obtaining a comprehensive (comprehensive) conclusion from each problem studied so that in the analysis a student's legal awareness regarding the prevention of unlawful acts, drug abuse, radicalism and terrorism.

\subsection{Techniques of Expertise Monitoring Data}

At this stage member checks are carried out with regard to the findings at the end of the study then the final assessment is carried out by the reader by first being disseminated and discussed.

\subsection{Research Flow Chart}

The time of this research is planned to be carried out approximately 4 months since the proposal is approved for implementation. The mechanism of work to be carried out in this study can be seen as follows:

Found:

- Student legal knowledge

- Understanding of student law

- Student attitude

- The pattern of legal behavior of students

First-hand study of student legal awareness

Discuss research on the results of students' legal awareness levels on law violations, drug abuse and prevention of radicalism and terrorism
- Produce an overview of how to increase legal awareness of Medan Area university students. 


\section{Discussion}

\subsection{The level of legal awareness of students towards acts against the law}

The level of legal awareness of students towards acts against the law uses four indicators, namely Legal Knowledge, Legal Understanding, Legal Attitudes and Legal Behavior.

These four indicators have been described in the questionnaire submitted in the form of 10 statements

\begin{tabular}{|l|c|c|}
\hline No & Indicator & Statement Number \\
\hline 1 & Legal Knowledge & Number 1 \\
\hline 2. & Legal Understanding & Numbers 3 through 5 \\
\hline 3. & Legal Attitude & Number 2,6,10 \\
\hline 4. & Legal Behavior & $\begin{array}{c}\text { Numbers 2,6,10 Numbers 7 } \\
\text { through 9 }\end{array}$ \\
\hline
\end{tabular}

The questionnaire will be filled by Medan Area University students as respondents and 60 people will be sampled based on researchers' statistical calculations.

For a full explanation, see the following discussion:

Table 1 Indicators of Legal Knowledge

\begin{tabular}{|c|c|c|}
\hline The answer & Frequency & Percentage \\
\hline Very Agree & 40 & 66,67 \\
\hline Agree & 17 & 28,33 \\
\hline Netral & 3 & 5 \\
\hline Disagree & 0 & 0 \\
\hline Very Disagree & 0 & 0 \\
\hline Total & 60 & 100 \\
\hline
\end{tabular}

Table 2 Indicators of Legal Understanding

\begin{tabular}{|c|c|c|}
\hline The answer & Frequency & Percentage \\
\hline Very Agree & 0 & 0 \\
\hline Agree & 0 & 0 \\
\hline Netral & 3 & 5 \\
\hline Disagree & 7 & 11,67 \\
\hline Very Disagree & 50 & 83 \\
\hline Total & 60 & 100 \\
\hline
\end{tabular}

Table 3 Indicators of Legal Attitudes

\begin{tabular}{|c|c|c|}
\hline The answer & Frequency & Percentage \\
\hline Very Agree & 24 & 40 \\
\hline Agree & 29 & 48,33 \\
\hline Netral & 7 & 11,67 \\
\hline Disagree & 0 & 0 \\
\hline Very Disagree & 0 & 0 \\
\hline Total & 60 & 100 \\
\hline
\end{tabular}


Table 4 Indicators of Legal Behavio

\begin{tabular}{|c|c|c|}
\hline The answer & Frequency & Percentage \\
\hline Very Agree & 0 & 0 \\
\hline Agree & 0 & 0 \\
\hline Netral & 8 & 13,33 \\
\hline Disagree & 15 & 25 \\
\hline Very Disagree & 37 & 61,67 \\
\hline Total & 60 & 100 \\
\hline
\end{tabular}

\subsection{The level of legal awareness of students against drug abuse}

The level of legal awareness of students towards Drug Abuse uses four indicators, namely Legal Knowledge, Legal Understanding, Legal Attitudes and Legal Behavior.

These four indicators have been described in the questionnaire submitted in the form of 10 statements.

\begin{tabular}{|l|l|l|}
\hline No & \multicolumn{1}{|c|}{ Indicator } & Statement Number \\
\hline 1 & Legal Knowledge & Number 6 \\
\hline 2. & Legal Understanding & Numbers 2,3, through 5 \\
\hline 3. & Legal Attitude & Numbers 7 through 10 \\
\hline 4. & Legal Behavior & Number 1 and 4 \\
\hline
\end{tabular}

The questionnaire will be filled by Medan Area university students as respondents and 60 people will be sampled based on researchers' statistical calculations.

For a full explanation, see the following discussion:

Table 5 Indicators of Legal Knowledge

\begin{tabular}{|c|c|c|}
\hline The answer & Frequency & Percentage \\
\hline Very Agree & 0 & 0 \\
\hline Agree & 0 & 0 \\
\hline Netral & 0 & 0 \\
\hline Disagree & 14 & 23,33 \\
\hline Very Disagree & 46 & 76,67 \\
\hline Total & 60 & 100 \\
\hline
\end{tabular}

Table 6 Legal Understanding Indicators

\begin{tabular}{|c|c|c|}
\hline The answer & Frequency & Percentage \\
\hline Very Agree & 0 & 0 \\
\hline Agree & 0 & 0 \\
\hline Netral & 3 & 5 \\
\hline Disagree & 4 & 11,67 \\
\hline Very Disagree & 52 & 83 \\
\hline Total & 60 & 100 \\
\hline
\end{tabular}


Table 7 Indicators of Legal Attitude

\begin{tabular}{|c|c|c|}
\hline The answer & Frequency & Percentage \\
\hline Very Agree & 24 & 40 \\
\hline Agree & 29 & 48,33 \\
\hline Netral & 7 & 11,67 \\
\hline Disagree & 0 & 0 \\
\hline Very Disagree & 0 & 0 \\
\hline Total & 60 & 100 \\
\hline
\end{tabular}

Table 8 Legal Behavior Indicators

\begin{tabular}{|c|c|c|}
\hline The answer & Frequency & Percentage \\
\hline Very Agree & 0 & 0 \\
\hline Agree & 0 & 0 \\
\hline Netral & 6 & 1 \\
\hline Disagree & 13 & 21,67 \\
\hline Very Disagree & 41 & 68,33 \\
\hline Total & 60 & 100 \\
\hline
\end{tabular}

3. The level of legal awareness of students towards the prevention of radicalism and terrorism

The level of legal awareness of students towards the Prevention of Radicalism and Terrorism uses four indicators, namely Legal Knowledge, Legal Understanding, Legal Attitudes and Legal Behavior.

These four indicators have been described in the questionnaire submitted in the form of 10 statements

\begin{tabular}{|l|l|l|}
\hline No & \multicolumn{1}{|c|}{ Indicator } & Statement Number \\
\hline 1 & Legal Knowledge & Number $1,2,4,8$ \\
\hline 2. & Legal Understanding & Number 3 \\
\hline 3. & Legal Attitude & Number 5,6,7 \\
\hline 4. & Legal Behavior & Numbers through 9 and 10 \\
\hline
\end{tabular}

The questionnaire will be filled by Medan Area university students as respondents and 60 people will be sampled based on researchers' statistical calculations. For a full explanation, see the following discussion:

Table 9 Indicators of Legal Knowledge

\begin{tabular}{|c|c|c|}
\hline The answer & Frequency & Percentage \\
\hline Very Agree & 42 & 70 \\
\hline Agree & 18 & 30 \\
\hline Netral & 0 & 0 \\
\hline Disagree & 0 & 0 \\
\hline Very Disagree & 0 & 0 \\
\hline Total & 60 & 100 \\
\hline
\end{tabular}


Table 10 Legal Understanding Indicators

\begin{tabular}{|c|c|c|}
\hline The answer & Frequency & Percentage \\
\hline Very Agree & 0 & 0 \\
\hline Agree & 0 & 0 \\
\hline Netral & 0 & 0 \\
\hline Disagree & 8 & 13,33 \\
\hline Very Disagree & 52 & 86,67 \\
\hline Total & 60 & 100 \\
\hline
\end{tabular}

Table 11 Indicators of Legal Attitude

\begin{tabular}{|c|c|c|}
\hline The answer & Frequency & Percentage \\
\hline Very Agree & 28 & 46,67 \\
\hline Agree & 19 & 31,67 \\
\hline Netral & 13 & 21,67 \\
\hline Disagree & 0 & 0 \\
\hline Very Disagree & 0 & 0 \\
\hline Total & 60 & 100 \\
\hline
\end{tabular}

Table 12 Legal Behavior Indicators

\begin{tabular}{|c|c|c|}
\hline The answer & Frequency & Percentage \\
\hline Very Agree & 0 & 0 \\
\hline Agree & 0 & 0 \\
\hline Netral & 3 & 5 \\
\hline Disagree & 16 & 26,67 \\
\hline Very Disagree & 41 & 68,33 \\
\hline Total & 60 & 100 \\
\hline
\end{tabular}

\section{Conclusion}

Based on the results of research for the level of legal awareness of students of the University of Medan Area Against Actions Against the Law, Drug Abuse, Prevention of Radicalism and Terrorism can be seen from two dimensions, namely the dimensions of understanding law and legal awareness, because these two things are very closely related in conducting a study of social symptoms of a particular legal problem. If 10 statements are calculated on indicators of legal knowledge and understanding of the law, then 60 percent of students have a high level of understanding, 10 percent in the very high category, 18 percent have a moderate level of understanding of the law, and 10 percent have a level of understanding of the law in the category low. While the other 2 percent have a very low level of understanding of the law. From the research data on the dimension of legal awareness, the level of Law Awareness of Medan Area University Students is 41 percent of students have a high level of legal awareness, 37 percent of students have a very high level of legal awareness, only 4 percent of students with low levels of legal awareness plus 3 percent have an awareness level the law is very low, while the other 15 percent have a moderate level of legal awareness. It can be concluded that most Medan Area University students have a high level of legal awareness, because a good understanding of law is owned by the students themselves. In this case, the 6th and 8th semester students as respondents were considered to 
be suitable and had sufficient understanding of something related to the statements contained in the questionnaire.

\subsection{Suggestion}

The role of religion in increasing the legal awareness of Medan Area University students is needed, "especially Islam as the religion of the majority of Medan Area University students and the many Islamic activities on the UMA campus are very strategic for the process of increasing the legal awareness of Medan Area University students, so it is hoped that through religious education, making students Medan Area University can be prevented from carrying out acts against the law, abusing drugs and carrying out acts of radicalism and terrorism.

\section{References}

Abdul Wahid, 2011, Kejahatan Terorisme Perspektif Agama, HAM dan Hukum, (Bandung: PT Refika Aditama).

Agsya, F. 2010. Undang-Undang RI Nomor 35 Tahun 2009 Tentang Narkotika dan UndangUndang RI Nomor 5 Tahun 1997 Tentang Psikotropika, Jakarta : Asa Mandiri.

Aulia Rosa Nasution, 2012, Terorisme Sebagai Kejahatan Terhadap Kemanusiaan: dalam Perspektif Hukum Internasional dan Hak Asasi Manusia, (Jakarta: Prenada Media Group)

AW. Widjaja, 1982, Kesadaran Hukum Manusia dan Masyarakat Pancasila, (Jakarta: CV.Era Swasta

Departemen Sosial RI. 2003 . Pola Operasional Pelayanan dan Rehabiltasi Sosial Korban Narkotika, Psikotropika dan Zat Adiktif Lainnya (NAPZA), Jakarta : Departemen Sosial RI.

Fachril, Yuanita. 2007. Narkoba, Mengenal Untuk Menangkal, Bandung : CV. Sarana Penunjang Pendidikan. Kaligis, O.C dan Soedjono Dirdjosiswoyo. 2006. Narkoba dan Peradilannya di Indonesia, Jakarta: O.C Kaligis \& Associates.

Hari Sasangka, 2003, Narkotika dan Psikotropika Dalam Hukum Pidana, Mandar Maju, Bandung

Luqman Hakim, 2004, Terorisme di Indonesis, (Surakarta: Forum Studi Islam Surakarta)

Moeljatno, 2008, Kitab Undang-Undang Hukum Pidana, (Jakarta: Bumi Aksara)

Ronny Hanitijo Soemitro, 1994,-- Metodologi Penelitian hukum , Jakarta Ghalia Indonesia

Sajipto Rahardjo, 1980, Hukum, Masyarakat Dan Pembangunan, Cetakan Kedua, Alumni Bandung

Soerjono Soekanto, 2012, Pokok-Pokok Sosiologi Hukum, (Jakarta: Rajawali Pers)

-----, 2004, Faktor-Faktor Yang Mempengaruhi Penegakan Hukum, Cetakan

Kelima, Raja Grafindo Persada Jakarta

Tumanggor, F. (2019). Handling of Narcotics Child Victims in Child Special Coaching Institutions Class I Tanjung Gusta, Medan, Budapest International Research and Critics Institute (BIRCI-Journal), P. 50-55.

Undang-Undang RI Nomor 35 Tahun 2009

Undang-Undang No. 15 Tahun 2003 tentang pemberantasan tindak pidana terorisme

https://media.neliti.com/media/publications/177473-ID-none.pdf

https://nasional.sindonews.com/read/1257498/15/40-pengguna-narkoba-pelajar-mahasiswa1510710950

The Encylopedia Americana, Volume 19, Americana Corporation, New York, 1971 